\title{
Divergent Opinions in the Pre-Issue Market and the Pricing of Initial Public Offerings
}

\author{
Ronnie Qi ${ }^{\text {a }}$ \\ St. John's University \\ Xianming Zhou ${ }^{\text {b }}$ \\ University of Hong Kong
}

\begin{abstract}
Investors in an initial public offering (IPO) face a lack-of-information problem: they have to guess the new stock's aftermarket price. This problem poses a risk in the absence of a consensus among the investors' pre-issue opinions and the risk is greater when the opinions are more divergent. We model this lack-of-information problem in an IPO, where, to place a certain number of the shares, the issuer adjusts the offer price to accommodate the difference in the demand between the pre-issue market and the aftermarket. By examining a large sample of IPOs, we obtain strong evidence in support of the model's predictions for IPO underpricing and sales.
\end{abstract}

JEL classification: G14, G32

Keywords: Investor opinions, risk, IPOs, underpricing

\footnotetext{
${ }^{a}$ Peter J Tobin College of Business, St. John's University, Jamaica, NY 11439 USA; Tel.: +1 (718) 9907320; E-mail: qir@stjohns.edu.

${ }^{\mathrm{b}}$ School of Economics and Finance, University of Hong Kong, Pokfulam Road, Hong Kong, Tel: + 852-28578564; E-mail: xianming.zhou@hku.hk.
} 
Participants in an initial public offering (IPO), including the issuer, underwriter, and investors, face a lack-of-information problem. That is, there is no available information on the new stock's current market price. Hence, an investor who wishes to purchase the stock from the IPO has to guess its market value. When there is no consensus in the pre-market beliefs, this lack-of-information problem poses a risk to the investor. His guess may suffer from a systematic bias owing to the divergent opinions of heterogeneous investors. That is, his personal belief may systematically deviate from the market's expectation. This risk is greater when the opinions are more divergent. On the other hand, divergent opinions do not pose a risk in an efficient secondary market where the stock price is public information and all investors take it as the market value regardless of differing personal beliefs and preferences.

To model this lack-of-information problem, we start with the pre-market demand of heterogeneous investors for the new issue. As the risk arising from this problem increases when the opinions are more divergent, we derive the demand as a decreasing function of the degree of opinion divergence. We then characterize the issuer's two-dimension decision, IPO pricing and sales, constrained by the pre-market demand and the issuer's sales objective. We obtain the closed-form solution and derive testable predictions: As the degree of opinion divergence increases (i) underpricing increases and (ii) fewer shares are placed in the IPO.

Many previous studies have modeled IPO underpricing. Such models assume information asymmetry, one way or the other, between the different participants in an IPO. For instance, Rock (1986) argues that information is asymmetric between investors, where some investors are informed and others are uninformed. Consequently, there is an adverse selection problem that requires the issue to be underpriced to attract uninformed investors. Information can also be asymmetric between the issuer and investors. When the issuer is better informed than 
investors of the firm's fundamentals, as in Allen and Fauhaber (1989), Grinblatt and Hwang (1989), and Welch (1989), high quality issuers may have an incentive to use underpricing as a signal to differentiate themselves from low quality issuers. In particular, as Benveniste and Spindt (1989) and Sherman and Titman (2002) argue, institutional investors may possess better information than the issuer and the underwriter on the market demand. Hence, underpricing may be used to motivate investors to truthfully reveal costly private information.

Instead of assuming asymmetric information, our model builds on the lack-of-information problem facing all participants in an IPO: there is initially no public or private information on the market demand. This problem in the presence of divergent opinions leads to underpricing. By specifying the degree of divergence, our model establishes a link between IPO decision variables and any information-related factors, including asymmetric information, that affect the difficulty of pricing. Another distinct feature of our model is that it simultaneously characterizes two interrelated IPO decisions, that is, the offer price and the sale of the stock. As our results are derived in terms of pre-market opinion divergence, our model gives predictions that are directly testable.

In the second part of this study, we test our predictions using the sample of IPOs conducted during the period 1991-2004. We identify three proxy variables for the degree of pre-market opinion divergence, which are the filing price range, the absolute value of price update, and the absolute value of error in prediction for the immediate aftermarket price. With each of the proxy variables, we document evidence in strong support of the model. We find that as the degree of pre-market divergence increases, IPO underpricing increases and the shares sold in the offering is reduced.

We note that our model is conceptually different from Miller's (1977) theory that predicts a 
link between the new stock's price and investor divergence in the post-issue market. In Miller (1977), a positive initial return occurs because the aftermarket price is pushed up, higher than the stock's intrinsic value, by optimistic investors. As such, IPO initial returns are viewed as new stock overvaluation in the aftermarket trading dictated by optimistic investors, instead of a consequence of new issue underpricing. The driving factor in Miller's (1977) model is a short sale constraint that deters a secondary market equilibrium price. Therefore, in this model, IPO short-term overvaluation is necessarily followed by long-term underperformance.

The paper proceeds as follows. Section I briefly discusses the literature of IPO underpricing and highlights our work in contrast to existing studies. Section II describes our model of the IPO decision in the pre-issue market with heterogeneous investors facing a lack-of-information problem. We derive the closed-form solution and discuss its predictions. Section III presents our empirical test for the model. In addition to various robustness checks, in this section we also discuss the essential differences between Miller (1977) and our model in terms of empirical findings. Section IV concludes the paper.

\section{Literature}

A number of studies in the finance literature examine the IPO underpricing phenomenon, of which many are based on asymmetric information. Rock (1986) presents a model assuming asymmetric information among investors, in which some investors are better informed than others. When there are good signals about the firm, the informed investors will crowd out the uninformed ones. Hence, the orders of the uninformed investors are filled only if the signals are bad and the shares are unwanted by the informed investors. In order to make the orders attractive to uninformed investors, the offering firm must set the price of the new shares at a 
discount. More recent studies address asymmetric information between issuers/underwriters and outside investors. In Allen and Faulhaber (1988), Grinblatt and Hwang (1989), and Welch (1989), issuers are better informed than the investors about the firm's future prospects and high quality issuers have incentives to signal their future prospect by underpricing the new issue. High-quality issuers are differentiated from low-quality issuers because only good firms are expected to recover their initial loss from subsequent seasonal offerings. On the other hand, Benveniste and Splidt (1989) model the IPO as an auction process, in which the underwriter uses the book-building process to collect private information from informed investors. The new stock is sold at a discount to compensate the investors for revealing costly private information. Consistent with this theory, Hanley (1993) provides evidence showing that underwriters do not fully adjust the offer price upward when the demand is strong. As underwriters only partially incorporate the positive information revealed during the book-building process in the finalized offer price, such investors are compensated by receiving more underpriced shares.

Apart from asymmetric information-based models, other theories have been proposed to explain IPO underpricing. Aggarwal, Krigman, and Womack (2002) argue that the issuer may strategically underprice the offer in order to generate information momentum by attracting more analyst research activities and media coverage. When such information momentum pushes up the demand, the owners benefit by selling the shares after the lockup period expires. Tinic (1988) and Hughes and Thakor (1992) contend that new issues are underpriced because the issuers and the investment banks want to avoid the legal risk. Rydqvist (1997) highlights the tax advantage of IPO underpricing to issuers as well as underwriters.

In this study, we model the lack-of-information problem in the presence of pre-market divergent opinions on the value of the IPO. Opinion divergence matters in the IPO market, 
where investors have to guess the stock's value without observing its current market price. In order to sell a certain number of the shares, the issuer underprices the issue to overcome the demand differential between the pre-market and the aftermarket. On the other hand, divergent opinions do not pose a risk in an efficient secondary market where stock price is public information, which presents the market value regardless of investors' personal beliefs and preferences.

In a related theory, Miller (1977) explains the phenomenon of IPO underpricing by the coexistence of investor divergence and short selling constraints. He argues that owing to short selling constraints, investor's divergence results in overvaluation of the new stock. This occurs because the equilibrium price will show the expectation of only those optimistic investors while the information of those pessimistic investors can not be incorporated into the stock price because of the short selling constraint. According to Miller, new issue returns are phenomena resulting from short-term overvaluation in the constrained aftermarket, instead of a result of pre-issue market underpricing.

A recent study by Edwards and Hanley (2007) provides a direct test of Miller's (1977) theory. By examining newly available data, they find that while greater short selling is observed in IPOs with positive high initial returns, short selling does not limit observed underpricing. The authors conclude that the evidence is inconsistent with theoretical models that predict high initial returns, in part, by assuming constraints on short sales. Consistent with Edwards and Hanley (2007), our empirical results in this study provide evidence to show that the variation in IPO underpricing is related to divergence factors in the pre-issue market but not to the variation in post-IPO divergence orthogonal to the pre-market factors. In other words, underpricing is not driven by investor divergence in the secondary market other than 
uncertainty factors unique to the pre-issue market.

\section{Theory}

\section{A. Investors' Decision: The Pre-market Demand}

The dynamics of stock price can be generally described by geometric Brownian motion:

$$
p_{t+\Delta t}=p_{t}+\mu p_{t} \Delta t+\sigma p_{t} \varepsilon \sqrt{\Delta t}
$$

where $p_{t}$ and $p_{t+\Delta t}$ are stock price at time $t$ and $t+\Delta t$, respectively, $\mu$ is the expected rate of return per unit of time, $\sigma$ is the price volatility, and $\varepsilon$ is a random drawing from a standardized normal distribution. The second term represents the expected return over the period of $\Delta t$, and the third term represents the stock's fundamental risk.

To apply this model to the pricing of an IPO, we consider a risk-averse investor, $i$, who faces an investment decision in a new issue at time $t=0$. He either purchases one share of the stock from the IPO, paying the offer price $p_{0}$, or uses the same amount of money to purchase risk-free bonds for a short period, $\Delta t$, until the share price is realized in the immediate aftermarket. Given that any shares purchased from the pre-market can be sold immediately after the stock starts to trade, we examine the investor's expected utility in the immediate aftermarket at time $t=\Delta t$.

The market value of the new stock is unknown in the pre-market; hence, the investor has to guess this value based on his personal belief. Assume that the stock is worth $V_{i}^{e}$ to the investor. As investors are heterogeneous, this value can be different from the market valuation. Without the information on market demand, the investor's best guess of the stock value is: 


$$
p_{i}^{e}=V_{i}^{e}+\theta_{i}
$$

The error term $\theta_{i}$ presents the investor's subjective assessment of the deviation of his personal valuation from market valuation, which depends on opinion divergence in the pre-issue market. In the investor's eyes, $\theta_{i}$ is uniformly distributed between $-\delta$ and $\delta$, thus it has zero mean and variance of $\frac{1}{3} \delta^{2}$. We take $\delta$ to be the measure of the degree of opinion divergence. For simplicity and without losing generality, we use $\delta$ for all investors.

Using $p_{i}^{e}$ to replace $p_{t}$ in equation (1), we obtain the investor's expected aftermarket price at time $\Delta t$ conditional on his pre-market belief:

$$
p_{\Delta t}^{e} \mid p_{i}^{e}=p_{i}^{e}+\mu_{i}^{e} p_{i}^{e} \Delta t+\sigma_{i}^{e} p_{i}^{e} \varepsilon \sqrt{\Delta t}
$$

where the superscript $e$ denotes expectation. $\mu_{i}^{e}$ and $\sigma_{i}^{e}$ are parameters based on the investor's belief, which are related to $p_{i}^{e}$.

In a secondary market, $p_{t}$ is publicly observed, so $p_{i}^{e}=p_{t}, \mu_{i}^{e}=\mu, \sigma_{i}^{e}=\sigma$ and, as equation (1) shows, investors only bear the fundamental risk. For the new issue, there is another source of risk, namely, the investor's personal belief may be systematically different from the market expectation $V$ (or $V_{i}^{e} \neq V$ ). Without the market valuation information, this difference is not observed and cannot be estimated by investors holding divergent opinions. ${ }^{1}$

On the other hand, after the book-building process is completed, the issuer/underwriter

\footnotetext{
${ }^{1}$ In reality, investors do have some information on a new issue that can be used to adjust, to a certain extent, their personal valuation toward the market value. However, this real-world situation does not undermine the notion that individual investors are unable to systematically predict the value of a new issue, which is the starting point of our model.
} 
learns about the distribution of $V_{i}^{e}$ and thus the demand curve. Assume that $V_{i}^{e}$ is uniformly distributed between $V-h$ and $V+h$, where $h>0$. The aggregation of pre-market beliefs leads to the unbiased market valuation at the stock's intrinsic value, $E_{i}\left(V_{i}^{e}\right)=V$. This value determines the aftermarket price.

The distribution of $V_{i}^{e}$ is conceptually different from that of $\theta_{i}$. As a consequence of investor heterogeneity, the distribution of $V_{i}^{e}$ is objective and it continues to be present in the secondary market. On the other hand, the distribution of $\theta_{i}$ is subjective, which disappears after the stock price is realized in the aftermarket where all investors set $p_{i}^{e}=p_{t}$.

Substituting relation (2) into equation (3) and assuming independence between $\theta_{i}$ and $\varepsilon$, we have:

$$
\begin{gathered}
E\left(p_{\Delta t}^{e} \mid p_{i}^{e}\right)=V_{i}^{e}\left(1+\mu_{i}^{e} \Delta t\right) \\
\operatorname{Var}\left(p_{\Delta t}^{e} \mid p_{i}^{e}\right)=\frac{1}{3} \delta^{2}\left(1+\mu_{i}^{e} \Delta t\right)^{2}+\sigma_{i}^{e 2} V_{i}^{e 2} \Delta t
\end{gathered}
$$

If the investor purchases the stock from the IPO, his certainty equivalent is

$$
V_{i}^{e}\left(1+\mu_{i}^{e} \Delta t\right)-\frac{1}{2} \rho\left[\frac{1}{3} \delta^{2}\left(1+\mu_{i}^{e} \Delta t\right)^{2}+\sigma_{i}^{e 2} V_{i}^{e 2} \Delta t\right]
$$

where $\rho$ is the coefficient of absolute risk-aversion, which, for simplicity, we use for all investors. On the other hand, the investor's utility from holding risk-free bonds is $p_{0}\left(1+r_{f} \Delta t\right)$. Therefore, he would choose to purchase the stock from the offering only if the following condition holds: 


$$
V_{i}^{e}\left(1+\mu_{i}^{e} \Delta t\right)-\frac{1}{2} \rho\left[\frac{1}{3} \delta^{2}\left(1+\mu_{i}^{e} \Delta t\right)^{2}+\sigma_{i}^{e 2} V_{i}^{e 2} \Delta t\right]>p_{0}\left(1+r_{f} \Delta t\right)
$$

Taking the investment period from the pre-market to the immediate aftermarket to be approximately one day, $\Delta t \approx 1 / 365$ and thus all terms with $\Delta t$ are relatively small. Ignoring those terms, we simplify the above condition as follows:

$$
V_{i}^{e}>p_{0}+\frac{1}{6} \rho \delta^{2} \quad \text { or } \quad p_{0}<V_{i}^{e}-\frac{1}{6} \rho \delta^{2}
$$

That is, the investor would purchase the stock from the offering if the offer price is lower than his believed value by an amount of $-\frac{1}{6} \rho \delta^{2}$. This amount increases with the degree of risk aversion and the investor's assessment of opinion divergence.

The investor's pre-market demand is

$$
D_{i}= \begin{cases}1 & \text { if } V_{i}^{e}>p_{0}+\frac{1}{6} \rho \delta^{2} \\ 0 & \text { otherwise }\end{cases}
$$

Suppose there are total $K$ investors in the market who are potential buyers of the issue. The number of investors whose guessed values are in the range of $d V_{i}^{e}$ is $\frac{K}{2 h} d V_{i}^{e}$. The aggregate pre-market demand as a function of the offer price $p_{0}$ is

$$
\begin{aligned}
D\left(p_{0}\right) & =\int_{p_{0}+\frac{1}{6} \rho \delta^{2}}^{V+h} \frac{K}{2 h} d V_{i}^{e} \\
& =\frac{K}{2}-\frac{K}{12 h} \rho \delta^{2}+\frac{K}{2 h}\left(V-p_{0}\right)
\end{aligned} .
$$

The demand curve has standard properties. It is decreasing in the offer price, and its 
sensitivity to price increases as investors become more homogeneous (i.e., as $h$ decreases). In particular, the second term in equation (5) indicates that the demand decreases as investors become more risk-averse and opinions are more divergent. This term presents a unique feature of the pre-market. To show the difference in demand between the pre-market and the aftermarket, let $\delta \rightarrow 0$ and $V=p_{0}=p_{t}$ to obtain $D\left(p_{t}\right)=\frac{K}{2}$. This is the equilibrium secondary-market demand, in which stock price is public information and the demand is completely inelastic to price regardless of investor heterogeneity.

\section{B. The Issuer's Decision}

Suppose the firm has total $N$ shares outstanding and is informed of the intrinsic value of the stock, $V$, after the book-building process. The firm's decision in the IPO involves two variables: the offer price $p_{0}$ and the number of shares to be sold $s N$, where $0 \leq s \leq 1$. The issuer's decision is to maximize the value of existing shareholders' investment subject to the pricing and sales constraints.

$$
\begin{aligned}
& \underset{P_{0}, s}{\operatorname{Max}} E(\pi)=N p_{0} s+N V(1-s)-\frac{c}{2}(s-\hat{s})^{2} \\
& \text { s.t. }\left\{\begin{array}{l}
N s \leq \frac{K}{2}-\frac{K \rho \delta^{2}}{12 h}+\frac{K}{2 h}\left(V-p_{0}\right) \\
p_{0} \leq V
\end{array}\right.
\end{aligned}
$$

The first term in the objective function is the proceeds from the sale of the shares and the second term is the value of existing shareholders' retained shares. The third term presents a cost to the shareholders that occurs as a result of a deviation of the sale from an exogenous, desired sales level, $\hat{s}$. Sales objectives may arise due to various reasons, such as existing shareholders' need for diversifying their investments and the issuer's concern over aftermarket liquidity, 
ownership structure, and control.

The first constraint describes the pre-market demand, which derives from equation (5). The second constraint specifies the valuation condition that requires the offer price to be equal or less than the shares' intrinsic value. The rational for this condition is the presumption that deliberates overpricing is not allowed. An alternative approach to the valuation constraint involves the addition of a penalty term in the objective function for the difference between the offer price and the intrinsic value, as in Khanna, Noe, and Sonti (2005). It is easy to show that these two approaches lead to qualitatively similar results.

We first discuss the solution for the special case of homogeneous opinions. With $\delta=0$, there must be $h \rightarrow 0$ and the pre-market demand requires efficient pricing $p_{0}=V$, resulting in $D=K / 2$. In this case, the demand is perfectly elastic and the supply dictates the trading volume. The solution in this case is equivalent to the aftermarket equilibrium, in which shareholders and the entrepreneur would be indifferent between keeping the existing shares and selling them to the public.

Proposition 1. With $\delta=0$, the equilibrium is characterized by fair pricing and a sale consistent with the trading in the efficient secondary market, in which $p_{0}=V$ and $s=\hat{s}=\frac{K}{2 N}$.

It is easy to verify that with $\delta=0$, the following solution satisfies all first-order conditions: $p_{0}=V, s=\hat{s}=\frac{K}{2 N}, \lambda_{1}=0$, and $\lambda_{2}=\frac{K}{2}$.

The following proposition presents the general solution with divergent pre-market opinions.

Proposition 2. With divergent opinions, $\delta>0$, there are two equilibrium outcomes:

(i) When $\delta$ is sufficiently small such that the following condition is satisfied, 


$$
\frac{\rho \delta^{2}}{6 h}\left(1+\frac{c K}{2 h N^{2}}\right) \leq 1,
$$

the IPO decision is characterized by fair pricing, in which

$$
\begin{gathered}
p_{0}=V \\
\text { and } \quad s=\frac{K}{2 N}\left(1-\frac{\rho \delta^{2}}{6 h}\right) .
\end{gathered}
$$

(ii) When condition (7) is violated, the IPO is underpriced and we have:

and

$$
\begin{gathered}
p_{0}=V-\left(\frac{c h K}{c K+2 h N^{2}}+\frac{\rho \delta^{2}}{6}-h\right)\left(1+\frac{2 h N^{2}}{c K+2 h N^{2}}\right)^{-1} \\
s=\frac{c K^{2}}{2 N\left(c K+2 h N^{2}\right)}-\frac{N K\left[\left(\rho \delta^{2}-6 h\right)\left(c K+2 h N^{2}\right)+6 c h K\right]}{6\left(c K+4 h N^{2}\right)\left(c K+2 h N^{2}\right)} .
\end{gathered}
$$

Proof: See Appendix A.

Equations (7) to (11) present the closed-form solution of the model, which determines IPO pricing and sale as a function of opinion divergence. We now derive more direct and testable predictions of the solution for the effects of opinion divergence on the IPO decision. Firstly and clearly, condition (7) is more likely to be violated when $\delta$ is greater. This implication gives us the first prediction:

Prediction 1. The more divergent the investors' opinions in the pre-issue market, the more likely an IPO is underpriced.

We then turn to the expected initial return on the issue, $R=\frac{V-p_{0}}{p_{0}}$. Equation (10) gives the offer price as a function of the stock's fundamental value and opinion divergence, which we 
denote as $p_{0}(V, \delta)$. Since $V$ is independent of $\delta$, we have $\frac{d R}{d \delta}=-\frac{1}{P_{0}^{2} V} \frac{d p_{0}}{d \delta}$. Using (8) and (10) in this result gives:

$$
\frac{d R}{d \delta}=\left\{\begin{array}{lc}
\frac{\rho \delta}{3 P_{0}^{2} V} \times \frac{c K+2 h N^{2}}{c K+4 h N^{2}} & \text { for underpriced IPOs } \\
0 & \text { for fairly priced IPOs }
\end{array}\right.
$$

The effect of opinion divergence on IPO return is non-negative and nonlinear. While opinion divergence does not affect the return for ex ante fairly priced IPOs, it increases underpricing for ex ante underpriced IPOs. This result leads to our second prediction:

Prediction 2. IPO return increase as the degree of opinion divergence increases. This positive link comes from ex ante underpriced IPOs.

In our model, the selling of existing shares presents an equally important dimension, as the pricing, of the IPO. Equations (9) and (11) give the closed-form solution for the sale as a function of opinion divergence, which we denote as $s(\delta)$. Note that the demand constraint is binding in equilibrium. Using this condition and by differentiation with respect to $\delta$ we obtain $\frac{d s}{d \delta}=-\frac{K}{6 h N}\left(\rho \delta+3 \frac{\partial p_{0}}{\partial \delta}\right)$. Using (9) and (11) in this result gives:

$$
\frac{d s}{d \delta}= \begin{cases}-\frac{K \rho \delta}{6 h N} \times \frac{2 h N^{2}}{c K+4 h N^{2}} & \text { For underpriced IPOs } \\ -\frac{K \rho \delta}{6 h N} & \text { For fairlypricedIPOs. }\end{cases}
$$

The sale of existing shares is negatively associated with the degree of opinion divergence.

Moreover, this negative association is stronger for ex ante fairly-priced IPOs. This implication 
gives our third testable prediction:

Prediction 3. The sale of existing shares in an IPO decrease as the degree of opinion divergence increases. This negative relationship is stronger with ex ante fairly-priced IPOs than with ex ante underpriced IPOs.

This prediction is consistent with the literature of shares overhang in an IPO. The shares overhang is defined as the ratio of the number of shares retained by existing owners relative to the number of shares filed for sale to the public. Loughran and Ritter (2002) find that IPOs with greater shares overhang, that is, fewer shares sold relative to shares retained, might be more severely underpriced. They offer a prospect theory to explain this observation: the wealth loss of underpricing is compensated by the value gain to the non-selling shareholders. Bradley and Jordan (2003) also find that IPOs with greater overhang are underpriced more than those with smaller degrees of overhang.

Our model provides an alternative explanation why the firm may want to float fewer shares. As opinion divergence increases, the increased risk due to the lack-of-information problem reduces the pre-market demand. This negative effect of increased risk is asymmetric between fairly-priced IPOs and underpriced IPOs. For fairly-priced IPOs, this effect leads to a full adjustment in the shares sold; for underpriced IPOs, this effect only requires a partial adjustment because it is partly offset by the reduced price because of the resulting greater underpricing.

A further interesting prediction of equations (12) and (13) is that as the uncertainty in the firm's output or the degree of risk aversion increases, underpricing increases and fewer shares are sold in the IPO. This prediction is consistent with the notion that the lack-of-information 
problem poses an additional risk to investors, who in turn demand higher IPO return and whose demand for the new stock declines. An important implication here is that there is a link between the IPO decision variables and a broad range of risk related factors.

\section{Evidence}

We use three variables as a proxy for the degree of pre-market opinion divergence. The first proxy is the price range filed with the SEC in the issuer's preliminary prospectus, which we calculate as the price range in dollars divided by the middle point of the preliminary offer prices. Intuitively, the price range is set wider when it is more difficult for the underwriter to determine the fair value of the new stock. We expect a direct association between opinion divergence and the difficulty in IPO pricing. In particular, this preliminary price range presents a desirable proxy for pre-market opinion divergence because it is unaffected by any marketing activities during the IPO process.

The absolute value of price update is the second proxy we use. This is the difference between the finalized offer price and the middle preliminary price, divided by the middle preliminary price. This proxy reflects the unexpected demand revealed after the book-building process. When there are more views on the aftermarket price or when such views are more divergent, there is a higher chance for the IPO to be initially mispriced in the sense that the preliminary offer price deviates greatly from the equilibrium-market price and, therefore, it is more likely for the offer price to be adjusted or to be adjusted to a greater extent.

The third proxy we use is the absolute value of the prediction error of a model that uses premarket firm variables to estimate the stock's aftermarket price. We call this proxy variable price residual. To obtain this variable, we first run regression for the 14th trading-day closing 
price on the firm's pre-issue variables, including revenue, shareholder equity, debt, net income, and industry and year dummy variables. Thereafter, we determine the price residual by normalizing the regression error, in absolute values, using the offer price. The 14th trading day price is used as a proxy for the IPO's equilibrium market value. ${ }^{2}$ As an indicator of unpredictable factors in new stock valuation, this proxy captures the influence of such factors, after controlling for pre-issue fundamental variables, on investors' opinions and thus unexpected demand. If the price residual is greater, then it is more difficult for the investors to gauge the aftermarket price. Consequently, the pre-market opinions are more divergent.

\section{A. Data}

We collect data on IPOs for the sample period from 1991 to 2004 from the Securities Data Company (SDC) New Issues Database. Following previous studies, we eliminate ADRs, closed-end funds, REITs, spin-offs, and unit issues by only choosing common stocks with the IPO flag equal to one. For each IPO, we collect information on offer prices, offer date, preliminary filing range, proceeds amount, shares offered, total shares outstanding before and after IPO, SIC code, and VC backing. To ensure that our results are not disproportionately affected by very small issuers, we exclude from the sample firms with an offer price less than $\$ 5$ per share.

The initial IPO return is calculated as the difference between the closing price at the end of the first trading day and the final offer price divided by the offer price. The shares sold in the IPO are the logarithm of total shares offered, including both primary and secondary shares, divided by the total shares outstanding after the IPO.

\footnotetext{
${ }^{2}$ Our results are qualitatively unchanged if we use the $21^{\text {st }}$ or $60^{\text {th }}$ day stock price. We also use the firm financial items from Compustat, and include all the IPO and non-IPO firms in the regressions and use a dummy variable to identify all the IPO firms. The results are qualitative unchanged.
} 
Information on accounting variables such as revenues, net income, and long-term debt are also collected from SDC. We use the data of such variables for the 12-month period immediately before the offering as the information available in the pre-issue market. To describe underwriter reputation, we follow Carter and Manaster (1990) and Carter, Dark and Singh (1998) and identify the lead underwriter from SDC and assign a rank, in a 10-point scale, based on the Loughran and Ritter (2002) classification. The average rank of all leading underwriters is used when there are more than one leading managers.

Panel A of Table 1 presents the descriptive statistics of our sample, totaling 5,286 IPOs. The average offer price and average first trading day closing price are $\$ 13.48$ and $\$ 16.60$, respectively. With the mean and median initial returns being $19.49 \%$ and $6.26 \%$, respectively, the distribution of the returns displays significant positive skewness as in Loughran and Ritter (2004). The average underwrite ranking in our sample is 6.83 and $33.7 \%$ of the issuing firms receive funding from venture capitalists.

Panel A also shows summary statistics for the three proxy variables of opinion divergence that is, offer price range, absolute price update, and absolute price residual, which are averaged at $13.61 \%, 14.65 \%$, and $0.44 \%$, respectively. Panel B further presents the Pearson correlation coefficients among the three divergence proxies. As expected, the proxy variables are positively correlated, with all $\mathrm{p}$-values significant at the $1 \%$ level. The strong positive correlations are consistent with the presumption that the proxy variables share the same information regarding pre-market opinion divergence.

Table 2 reports the mean summary statistics of our sample categorized by the three proxy variables of pre-IPO opinion divergence. With each divergence proxy, we rank the whole sample and divide the sample into three groups of different opinion divergence (low, median, 
and high). Panel A of Table 2 shows the statistics for the three groups based on price range. The average initial return is $23.2 \%$ for the group of high opinion divergence, which is notably higher than the average return of $14.2 \%$ for the group of low opinion divergence. Further, the group of issuers of high opinion divergence sells an average of $28.8 \%$ of total shares outstanding. This figure is about 10 percentage points lower than that with the low divergence group. Consistent with these two observations, the high divergence group is associated with low offer prices and small IPO proceeds.

Panels B and C present the summary statistics for the issuer groups classified by the absolute values of price update and price residual, respectively. Consistent with Panel A, the numbers in Panels B and C indicate that compared with the low divergence group, the high divergence groups are associated with lower offer prices and thus higher initial returns, and with fewer shares sold and lower IPO proceeds.

\section{B. Base Model Regressions}

According to our Prediction 1, IPOs associated with higher degree of pre-market divergence are more likely to be underpriced. We test this hypothesis using a logistic model, in which the dependent variable equals one if the initial return is positive and zero otherwise. The independent variables include a proxy for pre-market divergence and several controls that are commonly used in IPO pricing models. These control variables include proceeds (Ibbotson, Sindelar, and Ritter,1988; Tinic,1988; Schultz, 1993), stock exchange (Lowry and Shu, 2002), pre-issue market conditions (Hanley, 1993), and underwriter ranking (Carter and Manaster, 1990; Beatty and Welch, 1996). We also include in the regression dummy variables for high technology and the high-tech bubble period, which previous studies identify to be significant 
factors in IPO pricing (Loughran and Ritter, 2004). ${ }^{3}$

Hanley (1993) and others document a positive correlation between IPO initial returns and IPO price updates. This correlation is interpreted as evidence of reward for information production by institutional investors. Because we use the absolute value of price update as one of our opinion divergence measures, we also control for price update. To make sure our results are not driven by price update, we compared the regressions between those with and without the control for price update and found our results are very robust to the control.

Table 3 presents the results for the logistic regressions. Consistent with our Prediction 1, the estimated coefficients on the proxies of pre-market divergence are all positive and significant. The significance level is particularly high with the first two opinion divergence measures. Consistent with our Prediction 1, higher degree of opinion divergence in the pre-market leads to higher possibility for an IPO to be underpriced. The regressions in columns 2 and 3 further suggest the difference between price update and our second proxy of opinion divergence; after we control for price update, while the coefficient on this proxy remains highly significant and the magnitude is almost doubled.

We now proceed with our test for Predictions 2 and 3, the main results of our model. We run OLS regressions for the following specifications:

$$
\begin{aligned}
\text { Initial return } & =\alpha_{0}+\alpha_{1} \times \text { Proxy for divergence }+\alpha_{2} \times \text { Underwriter rank dummy } \\
& +\alpha_{3} \times \text { Price update }+\alpha_{4} \times \log (\text { Proceeds })+\alpha_{5} \times \text { Lagged Nasdaq return } \\
& +\alpha_{6} \times \text { VC-back dummy }+\alpha_{7} \times \text { High-tech dummy }+\alpha_{8} \times \text { Exchange dummy } \\
& +\alpha_{9} \times \text { Bubble dummy }
\end{aligned}
$$

\footnotetext{
${ }^{3}$ We also examined the regressions with industry dummies using the Fama-French Industry classification, which cause no meaningful changes in our results.
} 
$\log ($ Shares sold $)=\beta_{0}+\beta_{1} \times$ Proxy for divergence $+\beta_{2} \times$ Underwriter rank dummy

$+\beta_{3} \times$ Price update $+\beta_{4} \times \log$ of Proceeds $+\beta_{5} \times$ Lagged Nasdaq return

$+\beta_{6} \times$ VC-back dummy $+\beta_{7} \times$ High-tech dummy $+\beta_{8} \times$ Exchange dummy

$+\beta_{9} \times$ Bubble dummy

The dependent variable in model (14) is the percentage return on the IPO for the first trading day, which measures underpricing. The dependent variable in model (15) is the logarithm of the ratio of shares sold to total shares outstanding after IPO.

In Table 4, columns (1) to (3) present the regressions for IPO initial return, each with one opinion divergence proxy as the dependent variable. The coefficients on the three proxy variables are positive and statistically highly significant, which, consistent with our Prediction 2, show a positive effect of opinion divergence on underpricing. In column (1), the coefficient for the preliminary price range is 0.219 , which implies that for every one percentage point increase in the width of the filing price range, the new stock is underpriced by additional 0.219 percentage point. The estimates in columns (2) and (3) are very similar, where the opinion divergence proxy is the absolute value of price update and the absolute value of price residual, respectively. Both indicate a significant positive effect of opinion divergence on IPO initial return. Given that none of our proxy variables rely on asymmetric information, we view our results to be evidence of the link between IPO pricing and any factors that make IPO pricing more difficult and thus pre-market opinions more divergent.

The coefficient estimates for the control variables are mostly consistent with the existing literature. Several observations from the estimates are worth noting. Consistent with Hanley (1993) and others (e.g., Loughran and Ritter, 2004; Liungqvist and Wilhelm, 2002), the coefficient on price update is significantly positive. This result is referred to as the partial 
adjustment phenomenon, which explains underpricing as a reward scheme for information production. When underwriters discover a greater pre-market demand than anticipated, they partially adjust the price and leaves more money on the table to compensate informed investors for providing information during the book-building process. This control, however, has little effect on the coefficients for our opinion divergence proxies, which remain positive and highly significant in the regressions with or without this control variable being included.

The coefficient on prestigious underwriter ranking is positive and significant. This is consistent with the findings of Loughran and Ritter (2004) and Chemmanur and Krishnan (2007). Recent studies on the relationship between underwriter reputation and IPO underpricing find this relation mixed or complex; it is negative in the 1980s and turns positive in the 1990s. The positive association between underwriter reputation and IPO initial return supports the agency costs argument and the market power hypothesis. However, it is inconsistent with the certification argument.

Our estimates indicate a significant positive correlation between IPO underpricing and venture capital backing. This result does not support the presumed certification effect of VC on IPO pricing. Earlier studies, including Barry, Muscarella, Peavy, and Vetsuypens (1990), Megginson and Weiss (1991) and Schultz (1993), argue that in addition to providing funds to the issuer, $\mathrm{VC}$ also adds value to the firm by providing enterprises in management and monitoring. Owing to this role of VC as certification, VC-backed IPOs should be priced closer to their intrinsic firm values in comparison with those that are not VC-backed. However, more recent studies, such as Hamao, Packer and Ritter (2000), Brav and Gompers (1997), and Bradley and Jordan (2002), find that underpricing is in fact more severe among VC-backed firms during the 1990s. Hence, our result for the VC effect on underpricing is consistent with 
this more recent literature.

Bradley and Jordan (2002) and Ritter and Welch (2002) argue that firm managers time the market condition to decide to go IPO and the underwriters time the market to set up the offer price. Consistent with this argument, in our regressions, the coefficient on NASDAQ composite index return (which is a proxy for market condition and investor sentiment) is positive and significant. In addition, as expected, the coefficients on the dummy variables for high tech industry and the bubble period are positive and significant.

Columns (4) to (6) present our regressions for IPO sales, of which each includes an independent variable for the degree of pre-market opinion divergence. Consistent with our Prediction 3, the regressions show a negative effect of opinion divergence on the total primary and secondary shares sold at the IPO. All three coefficients for the divergence proxy are negative and significant at the one percent level. Take the coefficient on the filing price range as an example. At the value of -0.016 , it implies that the issuer will reduce the sale of the stock by about one percent of its total shares outstanding for every one percentage point increase in the preliminary price range.

The coefficients for the control variables in the regressions of IPO sales are mostly consistent with those in the regressions of IPO underpricing, of which most have a different sign while still significant. However, the coefficient on NASDAQ composite index return is no longer significant in the regressions for sales. This observation suggests that although the issuer and underwriter may have the incentive to time the market condition to make the IPO successful by realizing high initial returns, they do not adjust the sales following market conditions.

In summary, the regressions show significant effects of pre-market opinion divergence on 
IPO pricing and sales consistent with the predictions of our model. These effects are identified with each of our three opinion divergence variables, and they are robust to various controls. We note that the coefficient estimates are weaker with price residual than with other two proxy variables. One possible reason is the difference in sample size. The sample size is substantially reduced by the measure of price residual because it depends on the regression of IPO price on pre-issue firm variables that have missing values for many IPOs.

As discussed above, previous studies find that some observations on IPOs differ dramatically from time to time. To check whether our results are sensitive to sample periods, we divide the whole sample into two subsamples, the IPOs from 1991 to 1997 and those from 1998 to 2004, and rerun the regressions in Table 4 for the subsamples. Table 5 present our results from the subsample regressions, where the coefficients for control variables are not reported. Consistent with the whole sample results, the subsample regressions also indicate a significant positive effect of pre-market opinion divergence on IPO underpricing and a negative effect on IPO sales. This observation holds for both subsamples and there are no qualitative differences in the coefficient estimates between the subsamples.

\section{Further Tests}

\section{C.1. Control for Endogeneity}

In our base model regressions, we use a variety of variables to control for firm characteristics and market conditions. We now perform two-stage regressions to further address potential firm heterogeneity or other endogeneity factors. We use industry-level return volatility and average turnover ratio as our instrumental variables. Our reasons for choosing these two instrumental variables are as follows. On one hand, many studies, including Shalen 
(1993) and Harris and Raviv (1993), have documented a relationship between investor belief dispersion and stock volatility and trading volume. On the other hand, theory does not suggest any link between IPO underpricing (or sales) and these two variables and the extant empirical literature do not report any evidence on such a link. In addition, industry-wide stock volatility and trading volume are independent of idiosyncratic characteristic of issuers and hence are free of firm heterogeneity factors. We download the 48 industry daily return series from the French's website. The industry-level volatility and average turnover are computed for the 30 trading days preceding each IPO's first trading day. In the first stage, we regress each of our pre-market divergence proxies on industry return volatility and industry average turnover ratio. Then in the second stage, we run regressions of IPO initial returns and shares sold on the fitted values of opinion divergence obtained from the first-stage regressions, controlling for various firm and market variables.

Panel A of Table 6 presents the first-stage regressions. As expected, both industry volatility and trading volume are positively and significantly associated with the three opinion divergence variables. Panels B and C present our second-stage regressions. Compared with the base model estimates, the coefficients in these regressions are either similar (in two regressions) or greater (in seven regressions) and mostly remain highly significant. In particular, the results have noticeably improved with the regressions for IPO underpricing, in which all coefficients on the divergence variable are more than doubled and the $t$-ratios are higher. In conclusion, our instrumental variable regressions are consistent with the base model results, showing a significantly positive (negative) association of underpricing (shares sold) with the opinion divergence measures. These results lend further support to our model and, in particular, confirm that our estimates are not driven by unobserved firm heterogeneity. 


\section{C.2. Underpriced IPOs versus Fairly Valued IPOs}

Our model predicts that the link between opinion divergence and IPO decision variables is asymmetric between IPOs: the positive link between IPO underpricing and opinion divergence comes from ex ante underpriced IPOs, while the negative link between IPO sales and opinion divergence is stronger for ex ante fairly priced IPOs. To test this prediction, we first estimate the likelihood of underpricing for each IPO using the logistic models in Table 6 (Panel B). We then divide the total sample into two subsamples at the median predicted likelihood, morelikely underpriced IPOs and less-likely underpriced IPOs, and run regressions for each subsample. In order to minimize potential endogeneity, we use the predicated values of opinion divergence measures obtained from the first-stage regressions in Table 6 as our independent variables for the degree of opinion divergence.

Panel A in Table 7 reports the results of the regressions for IPO initial return. For the subsample of more-likely-underpriced IPOs, the positive relation between underpricing and opinion divergence is notably stronger than those for the total sample regressions discussed above. The coefficients on the divergence proxies now have greater magnitude and are with higher significance levels. For less-likely-underpriced IPOs, however, the corresponding coefficient estimates are either insignificant or economically weaker. This asymmetric pattern of the underpricing-opinion divergence relation confirms our model's prediction.

The regressions of shares sold are reported in Panel B, which also show an asymmetric pattern highly consistent with the model's prediction. The negative relation between shares sold and opinion divergence is significant and strong in all three regressions for the subsample of less-likely-underpriced IPOs. On the other hand, this relation is simply nonexistent for the subsample of more-likely underpriced IPOs, for which the coefficients are statistically not 
different from zero in all three regressions.

\section{C.3. IPO Proceeds}

We have so far established evidence to show that as the degree of divergence in pre-market opinions increases, the IPO is sold at a higher discount and fewer shares are placed. A direct implication of this finding is that the total amount of proceeds raised from the IPO decreases when the degree of divergence is higher. We test this implication by running regressions of IPO proceeds on an opinion divergence proxy. Table 8 presents the results for this test, where the dependent variable is the logarithm of total amount of money raised from both primary and secondary shares offered. Consistent with our separated regressions for IPO initial return and shares sold, all regressions in Table 8 show a significant negative correlation between IPO proceeds and the degree of opinion divergence. In particular, the results substantially improve after we control for potential endogeneity. In the two-stage regressions reported in columns (4) to (6), the coefficients on opinion divergence become five to nine times as high as the corresponding OLS estimates reported in columns (1) to (3).

\section{Pre-market Divergence versus Aftermarket Divergence}

Miller (1977) predicts a link between IPO valuation and investor opinion divergence in the secondary market. In the presence of short selling constraints, investor divergence results in new stock overvaluation due to the demand of optimistic investors, and overvaluation increases when opinions are more divergent. This theory suggests an alternative explanation of IPO initial return: it is a phenomenon of short-term overvaluation in the aftermarket trading. Clearly, this theory is conceptually different from IPO underpricing theories, including ours, that model IPO initial return as a consequence of discounted sale of the new stock. As both Miller's (1977) 
theory and ours predict a positive relation between IPO initial return and investor divergence, the important question here is whether we can distinguish between the two theories empirically. Indeed, some recent studies report a positive association between IPO initial return and postIPO divergence measures and interpret this association as evidence of overvaluation consistent with Miller (Houge, Loughran, Suchanek, and Yan, 2001; Gao, Mao, and Zhong, 2003). However, a recent study by Edwards and Hanley (2007) casts serious doubt on the short-sale constrained overvaluation argument. In a direct examination of the Miller (1977) theory, they find that short selling does not limit observed underpricing. They conclude that the evidence is inconsistent with theoretical models that predict high initial returns by assuming constraints on short sales.

In this section, we provide evidence to show that the link between IPO underpricing/sales and the degree of opinion divergence comes from pre-market divergence variables rather than from post-IPO divergence factors. For this purpose, we identify two measures of post-IPO opinion divergence and, in two steps, examine their relations with IPO initial return and sales. We first perform regressions of the post-IPO divergence measures on the pre-IPO divergence proxies, and decompose each post-IPO measure into two parts: the component that is explained by a pre-IPO proxy and the residual component. We then run regressions of IPO initial return and sales on these two components. Differences in coefficients between the two components allow us to compare their relations with the IPO decision variables.

There are essential differences in underlying factors affecting divergent opinions between the pre-issue market and the aftermarket. By definition and according to our calculation methods, the pre-market proxies we use in above regressions capture opinion divergence arising from the missing information on the stock's current market price. This problem 
disappears after the stock begins to trade. Presumably, divergence in opinion still exists in the secondary market because of the co-existence of investor heterogeneity (e.g., in preferences) and uncertainty in the firm. The secondary market divergence can be gauged by variations in analyst forecasts and investors' trading activities. Benveniste, Ljungqvist, Wilhelm and $\mathrm{Yu}$ (2003) suggest that the uncertainty in new issue valuation largely comes from the uncertainty in the firm's future growth. Thus we use analyst dispersion in firm long run growth forecast (ADIGF) as our first measure of post-IPO divergence. We obtain analyst forecasts of long run growth from $\mathrm{I} / \mathrm{B} / \mathrm{E} / \mathrm{S}$ summary history database and use as analyst dispersion the standard deviation of forecast normalized by the mean estimation during the year right after the IPO. To minimize potential bias caused by a small number of forecasts, we require a firm to have at least three financial analysts.

Our second measure of post-IPO divergence is the post-IPO 60 trading-day daily return volatility (TDDRV), adjusted by market volatility, which is also documented to reflect divergence in opinion. To obtain this measure, we retrieve stock price data for each IPO's first 60 trading days from the CRSP daily stock file, ${ }^{4}$ and run regression of the stock's daily return on CRSP market index return. The standard deviation of the regression residual gives us the measure of TDDRV.

Panel A of Table 9 presents our first-stage regressions, in which the post-IPO divergence variables, ADIGF and TDDRV, are regressed on each of the three pre-market divergence

\footnotetext{
${ }^{4}$ To avoid a potential offer price effect on the immediate aftermarket trading, we also examined the results by excluding the first a few, and up to 20 , trading days after IPO and found the results are qualitatively the same.
} 
proxies, filing price range, price update and price residual. ${ }^{5}$ The results highlight two observations on the relation and differences between the pre-market and aftermarket divergence measures. First, the coefficient on the pre-market divergence variable is positive and significant in all regressions. This result is expected because the common factors of investor heterogeneity and uncertainty in firm fundamentals cause divergent beliefs of investors in the pre-issue market and the aftermarket alike. Second, on the other hand, the small R-squared in all regressions in Panel A suggests the pre-market divergence measures explain only a small fraction of variation in secondary market divergence. In other words, the two groups of divergence variables reflect quite different underlying factors in shaping investor opinions in the market between before and after the IPO.

By collecting residual and fitted values from the first-stage regressions, we decompose the post-IPO divergence measures into two components: the component that is explained by premarket divergence and the residual component. Then, in the second stage, we run the base model regressions for IPO initial return and shares sold (as shown in Table 4) by replacing the pre-market divergence proxies with the two orthogonal components of post-IPO divergence. Panel B of Table 9 presents the regressions with ADIGF as the proxy for the degree of postIPO divergence. The coefficients show a striking difference in explanatory power between the two components of ADIGF. The predicted component has a significant and strong effect on IPO initial return and sales, consistent with the effects we document for the pre-market divergence measures. On the other hand, the coefficients on the residual component are either insignificant or have a magnitude that is less than 10 percent of the predicted component

\footnotetext{
${ }^{5}$ The sample size is dramatically reduced from 5,286 to 1,966 after we match the IPO sample with the $\mathrm{I} / \mathrm{B} / \mathrm{E} / \mathrm{S}$ database. The sample size is also reduced to 3,860 when the IPO sample is merged with CRSP daily stock file.
} 
counterpart. Panel C presents the regressions with TDDRV as the post-IPO divergence measure. The coefficients show a similar pattern of the substantial difference between the predicted component and the residual components of TDDRV.

These results allow us to draw two conclusions: (i) The link between IPO underpricing (or sales) and the post-IPO divergence measures comes from these measures' correlation with premarket divergence factors; (ii) much of the variations in the post-IPO measures is unrelated to pre-market factors and it does not explain the variations in IPO initial return and sales. These conclusions lend further support to our theory that the unique lack-of-information problem in the pre-IPO market results in divergent opinions that cause IPO underpricing. Edwards and Hanley (2007) provide evidence to reject the role of short-selling constraint - a necessary condition for Miller's (1977) prediction - in underpricing. Our findings further explain why a causal relation can still be observed between IPO initial return and post-IPO divergence measures.

\section{Conclusions}

The key difference between the pre-issue market and the aftermarket is the information of the stock's market price. Without this information, investors in the IPO face a common-sense uncertainty: They have to guess the aftermarket price and their guess may systematically deviate from the market expectation. This new-issue risk arises because of the coexistence of the missing information and heterogeneous investors. We model this lack-of-information problem and derive testable predictions for IPO pricing and sales. By examining a large sample of IPOs and using alternative proxies for pre-market opinion divergence, we document strong evidence consistent with our model's predictions. We find that when pre-market opinions are 
more divergent, the IPO is more likely to be underpriced or the degree of underpricing increases, and fewer shares are sold in the offering.

Previous studies identify a positive association between IPO underpricing and uncertainty in pricing (e.g., Beatty and Ritter, 1986; Lowry, Officer, and Schwert, 2007). This association is often explained by asymmetric information, assuming that it is more difficult to price an IPO when there is a greater degree of information asymmetry. In contrast to this argument, our model offers a standard risk-premium explanation of this association. Because the lack-ofinformation problem poses an additional risk, higher uncertainty in new issue pricing requires higher compensation to IPO investors. Equations (12) and (13) establish a direct link between the IPO decision variables on one hand, and uncertainty factors and investors' risk-taking behavior on the other. Indeed, any factors such as market sentiment and variations in premarket performance that make new issue valuation less accurate or more difficult are expected to lead to greater risk to the investors. Therefore, our model extends factors in IPO underpricing from information asymmetry to a broader range of economic variables. The link of many such variables to opinion divergence and thus their relevance to IPO underpricing can be conveniently measured and tested.

\section{Appendix A: Proof of Proposition 2}

The Lagrange function of the optimization problem (6) is

$$
L=N V(1-s)+N p_{0} s-\frac{c}{2}(s-\hat{s})^{2}+\lambda_{1}\left[\frac{K}{2}-\frac{K \rho \delta^{2}}{12 h}+\frac{K}{2 h}\left(V-p_{0}\right)-N s\right]+\lambda_{2}\left(V-p_{0}\right),
$$

where $\lambda_{1}$ and $\lambda_{2}$ are multipliers of the two constraints, respectively. 
The first-order derivatives are:

$$
\begin{gathered}
\frac{\partial L}{\partial p_{0}}=N s-\frac{K}{2 h} \lambda_{1}-\lambda_{2} \\
\frac{\partial L}{\partial s}=-N V+N p_{0}+c(\hat{s}-s)-\lambda_{1} N \\
\frac{\partial L}{\partial \lambda_{1}}=\frac{K}{2}-\frac{K \rho \delta^{2}}{12 h}+\frac{K}{2 h}\left(V-p_{0}\right)-N s \\
\frac{\partial L}{\partial \lambda_{2}}=V-p_{0}
\end{gathered}
$$

We first prove part (i). With $p_{0}=V$, the first-order condition $\frac{\partial L}{\partial \lambda_{1}} \geq 0$ requires $s<\hat{s}$

(where $\hat{s}=K / 2 N$ ), which means $\lambda_{1}>0$ because $\frac{\partial L}{\partial s} \leq 0$. Further, $p_{0}>0$ requires $\frac{\partial L}{\partial p_{0}}=0$

and thus $s>0$. Therefore, the four first-order conditions are all binding. Solving the binding conditions gives:

$$
s=\hat{s}\left(1-\frac{\rho \delta^{2}}{6 h}\right), \quad \lambda_{1}=\frac{c \rho \delta^{2} \hat{s}}{6 h N}, \quad \lambda_{2}=N L\left(1-\frac{\rho \delta^{2}}{6 h}\right)-\frac{c \rho \delta^{2} L K}{12 h^{2} N}
$$

For $\lambda_{2}>0$, there must be

$$
\frac{\rho \delta^{2}}{6 h}\left(1+\frac{c K}{2 h N^{2}}\right)<1
$$

In other words, when (A6) is satisfied, the solution with $p_{0}=V$ and $s=\hat{s}\left(1-\frac{\rho \delta^{2}}{6 h}\right)$ is optimal.

We then prove part (ii). With $p_{0}<V$, there are $\frac{\partial L}{\partial \lambda_{2}}>0$ and $\lambda_{2}=0$. From $\frac{\partial L}{\partial p_{0}}=0$

(because $p_{0}>0$ ), there are $s=0$ and $\lambda_{1}=0$, or $s>0$ and $\lambda_{1}>0$. Because $s$ and $\lambda_{1}$ cannot 
both be zero (otherwise, $p_{0}$ becomes indeterminate), there must be $s>0$ and $\lambda_{1}>0$, which require $\frac{\partial L}{\partial s}=0$ and $\frac{\partial L}{\partial \lambda_{1}}=0$.

From $\frac{\partial L}{\partial p_{0}}=0$ and $\frac{\partial L}{\partial s}=0$ and noting that $\lambda_{2}=0$, we obtain

$$
s=\frac{c K \hat{s}-N K\left(V-p_{0}\right)}{c K+2 h N^{2}}
$$

Using this result in $\frac{\partial L}{\partial \lambda_{1}}=0$ gives:

$$
P_{0}=V-\left(\frac{c h K}{c K+2 h N^{2}}+\frac{\rho \delta^{2}}{6}-h\right)\left(1+\frac{2 h N^{2}}{c K+2 h N^{2}}\right)^{-1}
$$

Substituting (A8) back to (A7) yields:

$$
s=\frac{c K^{2}}{2 N\left(c K+2 h N^{2}\right)}-\frac{N K\left[\left(\rho \delta^{2}-6 h\right)\left(c K+2 h N^{2}\right)+6 c h K\right]}{6\left(c K+4 h N^{2}\right)\left(c K+2 h N^{2}\right)}
$$

\section{References}

Aggarwal, R. K., L. Krigman, and K. L. Womack. "Strategic IPO Underpricing, Information Momentum, and Lockup Expiration Selling.” Journal of Financial Economics, 66 (2002), 105-137.

Allen, F., and G. R. Faulhaber. "Signaling by Underpricing in the IPO Market.” Journal of Financial Economics, 23 (1989), 303-323.

Beatty, Randolph, and Jay Ritter, 1986, "Investment Banking, Reputation, and the 
Underpricing of Initial Public Offerings,” Journal of Financial Economics 15, 213-232.

Barry, Christopher B., Chris J. Muscarella, John W. Peavy, III, and Michael R. Vetsuypens, 1990, The role of venture capital in the creation of public companies: Evidence from the going public process, Journal of Financial Economics 27, 447-471.

Beatty, Randolph P., and Ivo Welch, 1996, Issuer expenses and legal liability in initial public offerings, Journal of Law and Economics 39, 545-602.

Benveniste, L. M., and P. A. Spindt. "How Investment Bankers Determine the Offer Price and Allocation of New Issues.” Journal of Financial Economics, 24 (1989), 343-361.

Benveniste, L. M., A. Ljungqvist, W. J. Wilhelm, and X. Y. Yu, 2003, Evidence of information spillovers in the production of investment banking services, Journal of Finance 58, 577608.

Bradley, D., and B. Jordan. "Partial Adjustment to Public Information and IPO Underpricing." Journal of Financial and Quantitative Analysis, 37 (2002), 595-616.

Bradley, D., B. Jordan, and J. R. Ritter. "The Quiet Period Goes out with a Bang.” Journal of Finance, 58 (2003), 1-36.

Brav, Alon and Paul A. Gompers, 1997, Myth or reality? The long-run underperformance of initial public offerings: Evidence from venture and non-venture capital-backed companies, Journal of Finance 52, 1791 - 1821.

Carter, R.; F. Dark; and A. Singh. "Underwriter Reputation, Initial Returns and the Long-Run Performance of IPO Stocks.” Journal of Finance, 53 (1998), 285-311.

Carter, R., and S. Manaster, 1990, Initial public offerings and underwriter reputation, Journal of Finance 45, 1045 - 1067.

Chemmanur, Thomas J and Karthik Krishnan. "Heterogeneous Beliefs, Short Sale Constraints, 
and the Economic Role of the Underwriter in IPOs", working paper, 2007.

Edwards, A. K., and K. W. Hanley, 2007, "Short Selling in Initial Public Offerings,” Working paper, U.S. Securities and Exchange Commission.

Gao, Yan, Connie X. Mao, and Rui Zhong, 2006, "Divergence of Opinion and Long-Term Performance of Initial Public Offerings,” Journal of Financial Research 29, 113-129.

Grinblatt, M., and C. Y. Hwang. "Signalling and the Pricing of New Issues.” Journal of Finance, 44 (1989), 393-421.

Hanley, K. W. "The Underpricing of Initial Public Offerings and the Partial Adjustment Phenomenon.” Journal of Financial Economics, 34 (1993), 231-250.

Hamao, Y., F. Packer and J. Ritter, 2000. Institutional affiliation and the role of venture capital: Evidence from initial public offerings in Japan. Pacific-Basin Finance Journal 8, 529-558.

Harris, M, and A. Raviv, 1993, Differences of Opinion Make a Horse Race, Review of Financial Studies 6, 473-506.

Houge, T., G. Suchanek, T. Loughran, and X. Yan, 2001, Divergence of Opinion, Uncertainty, and the Quality of Initial Public Offerings, Financial Management 30, 5-23.

Hughes, Patricia J., and Anjan V. Thakor, 1992, "Litigation Risk, Intermediation and the Underpricing of Initial Public Offerings,” Review of Financial Studies, 5, 709-742.

Ibbotson, Roger G., Jody L. Sindelar, and Jay R. Ritter, 1988, Initial public offerings, Journal of Applied Corporate Finance 1, 37-45.

Khanna, N., T. H. Noe, and R. Sonti, "Good IPOs Drive in Bad: Inelastic Banking Capacity and Persistently Large Underpricing in Hot IPO Markets.” Michigan State University, Manuscript (2005).

Loughran, T., and J. R. Ritter. "Why Don't Issuers Get Upset about Leaving Money on the 
Table in IPOs?" Review of Financial Studies, 15 (2002), 413-443.

Loughran, T., and J. R. Ritter. "Why Has IPO Underpricing Changed Over Time?” Financial Management, Vol. 33, No. 3 (Autumn 2004), pp 5-37.

Lowry, M., M. S. Officer, and G. W., Schwert, 2007, “The Variability of IPO Initial Returns," Working Paper, Penn State University.

Lowry, Michelle, and Susan Shu, 2002, Litigation risk and IPO underpricing, Journal of Financial Economics 65, 309-335.

Ljungqvist, A. P., and W. J. Wilhelm. "IPO Princing in the Dot-com Bubble." Journal of Finance, 58 (2003), 723-752.

Loughran, T., Ritter, J. R., 2002. Why don't issuers get upset about leaving money on the table in IPOs? Review of Financial Studies 15, 413-443.

Megginson, W., and K. Weiss. "Venture Capitalist Certification in Initial Public Offerings." Journal of Finance, 46 (1991), 29-48.

Miller, E. M. "Risk, Uncertainty, and Divergence of Opinion.” Journal of Finance, 32 (1977), 1151-1168.

Ritter, J. R., Welch, I., 2002. A review of IPO activity, pricing, and allocations. Journal of Finance 57, 1795-1828.

Rock, K. “Why New Issues Are Underpriced?” Journal of Financial Economics, 15 (1986), $187-212$

Rydqvist, Kristian. "IPO Underpricing as tax-efficient compensation". Journal of Banking and Finance 21 (1997), 295-313.

Schultz, P. (1993), "Unit initial public offering", Journal of Financial Economics, Vol. 34 No.2, pp.199-229. 
Shalen, C., 1993. Volume, Volatility, and the Dispersion of Beliefs. The Review of Financial Studies 6, 405-434.

Sherman, A. E., and S. Titman. "Building the IPO Order Book: Underpricing and Participation Limits with Costly Information.” Journal of Financial Economics, 65 (2002), 3-29.

Tinic, Seha M., 1988, “Anatomy of Initial Public Offerings of Common-Stock,” Journal of Finance, 43, 789-822.

Welch, I. "Seasoned Offerings, Imitation Costs and the Underpricing of Initial Public Offerings.” Journal of Finance, 44 (1989), 421-449. 


\section{Table 1. Summary Statistics}

The sample is from the SDC database, which consists of IPOs between January 1991 and December 2004. Closing price is the first-day closing price of the IPO, and offer price is the finalized offer price. Proceeds are the total proceeds for the IPO, in millions of dollars. Return is the percentage difference between the closing price and the offer price. Range is the difference between the original high and low filing prices divided by the middle filing price. Abs(residual) is the absolute value of the error in the regression for the 14th trading day closing price on pre-issue firm variables. The residual is normalized by the offer price.

Update is the difference between the final offer price and the midpoint of initial filing prices divided by the midpoint filing price. UW_rank is the 10-point scale for leading underwriter ranks assigned by Carter and Manaster (1990) and Carter, Dark and Singh (1998), modified by Loughran and Ritter (2004). Sold/SA is total shares offered, including both primary shares and secondary shares, divided by the total shares outstanding after the IPO. Revenue is the total revenues for the latest 12-month period, before the IPO, in millions of dollars. NI is the net income after taxes for the latest 12-month period, in millions of US dollars. Debt is the short-term debt plus senior debt and subordinated debt, in millions of dollars. VC is a dummy variable, which is equal to one if the IPO is backed by venture capitalists and equal to zero otherwise. Panel A reports the descriptive statistics of all variables. Panel B reports the correlation coefficients for the three proxy variables for the pre-market divergence in opinion. 


\begin{tabular}{|c|c|c|c|c|c|c|}
\hline & Observation & Mean & $\underline{\text { Median }}$ & $\underline{\text { Std Dev }}$ & $\underline{\text { Minimum }}$ & $\underline{\text { Maximum }}$ \\
\hline Closing Price & 5286 & 16.599 & 14.750 & 12.316 & 0.030 & 280.000 \\
\hline Log(Proceeds) & 5286 & 17.664 & 17.565 & 1.128 & 12.766 & 22.714 \\
\hline Return & 5286 & 19.493 & 6.250 & 44.068 & -99.823 & 626.667 \\
\hline Abs(update) & 5286 & 14.648 & 9.091 & 18.888 & 0 & 400.000 \\
\hline UW_rank & 5286 & 6.834 & 8.100 & 3.699 & 0 & 9.1 \\
\hline $\log (\operatorname{Sold} / \mathrm{SA})$ & 4150 & -1.159 & -1.181 & 0.724 & -5.677 & 3.311 \\
\hline Revenue & 2688 & 299.802 & 37.600 & 1511.47 & 0.100 & 29232.60 \\
\hline NI & 2751 & 6.193 & 1.500 & 195.990 & -6086.50 & 6671.90 \\
\hline
\end{tabular}

$\underline{\text { Panel B. Pearson Correlation coefficient among the three proxies of opinion divergence }}$

\begin{tabular}{|c|c|c|c|}
\hline & Offer Price Range & $\underline{\text { Abs(Update) }}$ & $\underline{\text { Abs(Residual) }}$ \\
\hline Offer Range & 1 & $0.231(<0.001)$ & $0.084(<0.001)$ \\
\hline Abs(Update) & $0.231(<0.001)$ & 1 & $0.187(<0.001)$ \\
\hline Abs(residual) & $0.084(<0.001)$ & $0.187(<0.001)$ & 1 \\
\hline
\end{tabular}




\section{Table 2. Mean Summary of Sample Characteristics Categorized by Opinion Divergence}

With each pre-market divergence proxy (filing price range, the absolute value of price update, and the absolute value of pricing residual), we rank all IPOs and divide the whole sample into three groups of different (low, medium, and high) opinion divergence. This table presents the summary characteristics of each IPO sample group. Sold/SA is total shares offered, including both primary shares and secondary shares, divided by the total shares outstanding after the IPO. $\mathrm{VC}$ is a dummy variable, which is equal to one if the IPO is backed by venture capitalists and equal to zero otherwise.

\begin{tabular}{|c|c|c|c|c|c|c|c|}
\hline Sample Group & Observation & IPO Return & Sold/SA & Proceeds & Offer & $\begin{array}{l}\text { Lead Rank } \\
\text { dummy }\end{array}$ & $\mathrm{VC}$ \\
\hline \multicolumn{8}{|c|}{ Panel A: Price Range as the Divergence Measure } \\
\hline Low Range & 1817 & 14.22 & 0.381 & 70.421 & 15.662 & 0.663 & 0.186 \\
\hline Medium Range & 1723 & 21.27 & 0.282 & 46.177 & 13.750 & 0.710 & 0.408 \\
\hline High Range & 1746 & 23.22 & 0.288 & 36.265 & 10.937 & 0.547 & 0.469 \\
\hline \multicolumn{8}{|c|}{ Panel B: Absolute Update as the Divergence Measure } \\
\hline Low Abs(Update) & 1836 & 10.48 & 0.390 & 53.490 & 13.668 & 0.585 & 0.238 \\
\hline Medium Abs(Update) & 1678 & 16.32 & 0.298 & 46.901 & 13.532 & 0.653 & 0.358 \\
\hline High Abs(Update) & 1772 & 31.80 & 0.265 & 41.867 & 13.228 & 0.686 & 0.464 \\
\hline \multicolumn{8}{|c|}{ Panel C: Absolute Prediction Residual as the Divergence Measure } \\
\hline Low abs(residual) & 642 & 15.70 & 0.291 & 40.265 & 13.949 & 0.630 & 0.334 \\
\hline Medium abs(Residual) & 650 & 16.11 & 0.290 & 34.346 & 13.242 & 0.631 & 0.342 \\
\hline High abs(Residual) & 648 & 20.85 & 0.278 & 29.385 & 11.586 & 0.611 & 0.409 \\
\hline
\end{tabular}




\section{Table 3. The Opinion Divergence and the Likelihood of IPO Underpricing}

This table presents the results of logistic regressions of IPO underpricing on proxies of opinion divergence in the pre-issue market. The dependent variable is equal to one if the IPO initial return is positive, and zero otherwise. The independent variables include a proxy for opinion divergence, which is preliminary offer price range, the absolute value of price update or the absolute value of pricing residual. Price range is the difference between the original high and low filing prices divided by their average. Price update is the difference between the final offer price and the midpoint filing price divided by the midpoint filing price. Residual is the normalized residual of the regression for the $14^{\text {th }}$ trading day closing price on firm characteristic variables available before the IPO. The control variables include the following: UW rank dummy is an indicator of leading underwriter prestige ranking, which is equal to one if the ranking is above eight and zero otherwise. Log proceeds is the logarithm of gross proceeds from the IPO in millions. NASDAQ return is the NASDAQ index return 14 days preceding the IPO. VC dummy is equal to one if the issue is backed by venture capitalists and zero otherwise. Tech dummy is equal to one if the firm is a high technology company and zero otherwise. Bubble dummy is equal to one if the IPO is in 1999 or 2000, and zero otherwise. NASDAQ dummy is equal to one if stock is listed on NASDAQ and zero otherwise. $p$-values are reported in parentheses. The signs $* * *, * *$, and * represent significance levels at $1 \%, 5 \%$, and $10 \%$, respectively. 


\begin{tabular}{|c|c|c|c|c|}
\hline \multirow[b]{2}{*}{ Independent Variable } & \multicolumn{4}{|c|}{ Dependent variable $=1$ if IPO return $>0$ ( 0 otherwise $)$} \\
\hline & (1) & (2) & (3) & (4) \\
\hline Intercept & $\begin{array}{l}0.271 \\
(0.638)\end{array}$ & $\begin{array}{l}0.085 \\
(0.873)\end{array}$ & $\begin{array}{l}1.803 \\
(0.001)\end{array}$ & $\begin{array}{l}-0.960 \\
(0.401)\end{array}$ \\
\hline Price range & $\begin{array}{l}\mathbf{0 . 0 5 1} * * * \\
(<0.001)\end{array}$ & & & \\
\hline | Price update | & & $\begin{array}{l}\mathbf{0 . 0 1 0} \text { *** }^{* *} \\
(<\mathbf{0 . 0 0 1 )}\end{array}$ & $\begin{array}{l}\mathbf{0 . 0 1 9})^{* * *} \\
(<0.001)\end{array}$ & \\
\hline | Residual | & & & & $\begin{array}{l}0.039 * \\
(0.084)\end{array}$ \\
\hline Price update & $\begin{array}{l}0.032 * * * \\
(<0.001)\end{array}$ & & $\begin{array}{l}0.036 * * * \\
(<0.001)\end{array}$ & $\begin{array}{l}0.038 * * * \\
(<0.001)\end{array}$ \\
\hline UW rank dummy & $\begin{array}{l}0.173 * * \\
(0.016)\end{array}$ & $\begin{array}{l}0.172 * * \\
(0.014)\end{array}$ & $\begin{array}{l}0.161 * * \\
(0.024)\end{array}$ & $\begin{array}{l}0.022 \\
(0.868)\end{array}$ \\
\hline Log proceeds & $\begin{array}{l}-0.018 \\
(0.582)\end{array}$ & $\begin{array}{l}0.011 \\
(0.717)\end{array}$ & $\begin{array}{l}-0.082 * * * \\
(0.008)\end{array}$ & $\begin{array}{l}0.114^{*} \\
(0.088)\end{array}$ \\
\hline NASDAQ return & $\begin{array}{l}0.033 * * * \\
(<0.001)\end{array}$ & $\begin{array}{l}0.039 * * * \\
(<0.001)\end{array}$ & $\begin{array}{l}0.030 * * * \\
(<0.001)\end{array}$ & $\begin{array}{l}0.038 * * * \\
(0.004)\end{array}$ \\
\hline VC dummy & $\begin{array}{l}0.159 * * \\
(0.040)\end{array}$ & $\begin{array}{l}0.238^{* * * *} \\
(0.001)\end{array}$ & $\begin{array}{l}0.224 * * * \\
(0.003)\end{array}$ & $\begin{array}{l}0.159 \\
(0.206)\end{array}$ \\
\hline Tech Dummy & $\begin{array}{l}0.140 * \\
(0.077)\end{array}$ & $\begin{array}{l}0.306^{* * * *} \\
(<0.001)\end{array}$ & $\begin{array}{l}0.184 * * \\
(0.018)\end{array}$ & $\begin{array}{l}0.132 \\
(0.318)\end{array}$ \\
\hline Bubble dummy & $\begin{array}{l}0.154 \\
(0.136)\end{array}$ & $\begin{array}{l}0.278 * * * \\
(0.005)\end{array}$ & $\begin{array}{l}0.143 \\
(0.164)\end{array}$ & $\begin{array}{l}0.217 \\
(0.454)\end{array}$ \\
\hline NASDAQ dummy & $\begin{array}{l}0.182 * * * \\
(0.008)\end{array}$ & $\begin{array}{l}0.292 * * * \\
(<0.001)\end{array}$ & $\begin{array}{l}0.270 * * * \\
(<0.001)\end{array}$ & $\begin{array}{l}0.181 \\
(0.114)\end{array}$ \\
\hline Observation & 5286 & 5286 & 5286 & 1940 \\
\hline
\end{tabular}




\section{Table 4. IPO Underpricing, Shares Sold, and Opinion Divergence: Base Regressions}

This table presents OLS regressions for IPO underpricing and sales on proxies of divergence of pre-market opinions. The dependent variable in the regressions in columns (1) to (3) is IPO initial return, which is the percentage difference between the first-day closing price and the offer price. The dependent variable in the regressions in columns (4) to (6) is the logarithm of shares sold divided by the total number of shares outstanding after IPO. UW rank dummy is an indicator of leading underwriter prestige ranking, which is equal to one if the ranking is above eight and zero otherwise. Log proceeds is the logarithm of gross proceeds from the IPO in millions. NASDAQ return is the NASDAQ index return 14 days preceding the IPO. VC dummy is equal to one if the issue is backed by venture capitalists and zero otherwise. Tech dummy is equal to one if the firm is a high-technology company and zero otherwise. Bubble dummy is equal to one if the IPO is in 1999 or 2000, and zero otherwise. NASDAQ dummy is equal to one if stock is listed on NASDAQ and zero otherwise. White's (1980)

heteroskedasticity consistent $t$-statistic is reported in parentheses. The signs $* * *, * *$, and $*$ represent significance levels at $1 \%$, $5 \%$, and $10 \%$, respectively. 


\begin{tabular}{|c|c|c|c|c|c|c|}
\hline \multirow[b]{2}{*}{ Independent Variable } & \multicolumn{3}{|c|}{ Dependent Variable: Initial return } & \multicolumn{3}{|c|}{ Dependent Variable: Log(Shares sold/Total shares) } \\
\hline & (1) & (2) & (3) & (4) & $(5)$ & (6) \\
\hline Intercept & $\begin{array}{l}27.472 * * * \\
(2.81)\end{array}$ & $\begin{array}{l}20.375^{* *} \\
(2.29)\end{array}$ & $\begin{array}{l}31.849^{* *} \\
(2.11)\end{array}$ & $\begin{array}{l}-2.231 * * * \\
(-10.61)\end{array}$ & $\begin{array}{l}-2.573 * * * \\
(-12.53)\end{array}$ & $\begin{array}{l}-1.476^{* * *} \\
(-4.05)\end{array}$ \\
\hline Price range & $\begin{array}{l}0.219 * * * \\
(2.42)\end{array}$ & & & $\begin{array}{l}-0.016 * * * \\
(-9.27)\end{array}$ & & \\
\hline | Price update | & & $\begin{array}{l}0.345^{* * * *} \\
(3.21)\end{array}$ & & & $\begin{array}{l}-0.006 * * * \\
(-6.18)\end{array}$ & \\
\hline | Residual | & & & $\begin{array}{l}\text { 8.078** } \\
(1.96)\end{array}$ & & & $\begin{array}{l}-0.064^{* * *} \\
(-3.61)\end{array}$ \\
\hline Price update & $\begin{array}{l}0.790 * * * \\
(10.01)\end{array}$ & $\begin{array}{l}0.661 * * * \\
(12.71)\end{array}$ & $\begin{array}{l}0.660 * * * \\
(4.84)\end{array}$ & $\begin{array}{l}-0.003 * * * \\
(-5.65)\end{array}$ & $\begin{array}{l}-0.002 * * * \\
(-2.87)\end{array}$ & $\begin{array}{l}-0.003 * * * \\
(-4.05)\end{array}$ \\
\hline UW rank dummy & $\begin{array}{l}2.783 * * * \\
(2.90)\end{array}$ & $\begin{array}{l}2.096^{* *} \\
(2.15)\end{array}$ & $\begin{array}{l}3.159 * * \\
(2.23)\end{array}$ & $\begin{array}{l}-0.187 * * * \\
(-8.08)\end{array}$ & $\begin{array}{l}-0.181 * * * \\
(-7.74)\end{array}$ & $\begin{array}{l}-0.141 * * * \\
(-4.31)\end{array}$ \\
\hline Log proceeds & $\begin{array}{l}-1.399 * * * \\
(-2.68)\end{array}$ & $\begin{array}{l}-1.052 * * \\
(-2.14)\end{array}$ & $\begin{array}{l}-1.563 * \\
(-1.87)\end{array}$ & $\begin{array}{l}0.090 * * * \\
(7.65)\end{array}$ & $\begin{array}{l}0.102 * * * \\
(8.59)\end{array}$ & $\begin{array}{l}0.021 \\
(0.99)\end{array}$ \\
\hline NASDAQ return & $\begin{array}{l}0.686 * * * \\
(5.10)\end{array}$ & $\begin{array}{l}0.668 * * * \\
(4.88)\end{array}$ & $\begin{array}{l}0.435^{* * * *} \\
(2.42)\end{array}$ & $\begin{array}{l}-0.001 \\
(-0.09)\end{array}$ & $\begin{array}{l}-0.000 \\
(-0.10)\end{array}$ & $\begin{array}{l}-0.000 \\
(-0.13)\end{array}$ \\
\hline VC dummy & $\begin{array}{l}5.492 * * * \\
(4.43)\end{array}$ & $\begin{array}{l}4.798 * * * \\
(3.53)\end{array}$ & $\begin{array}{l}4.895^{* * * *} \\
(3.13)\end{array}$ & $\begin{array}{l}-0.073 * * * \\
(-3.22)\end{array}$ & $\begin{array}{l}-0.090 * * * \\
(-4.00)\end{array}$ & $\begin{array}{l}-0.004 \\
(-0.15)\end{array}$ \\
\hline Tech Dummy & $\begin{array}{l}8.054 * * * \\
(6.03)\end{array}$ & $\begin{array}{l}7.908 * * * \\
(5.87)\end{array}$ & $\begin{array}{l}3.788^{* * *} \\
(1.95)\end{array}$ & $\begin{array}{l}-0.137^{* * * *} \\
(-5.55)\end{array}$ & $\begin{array}{l}-0.156^{* * * *} \\
(-6.38)\end{array}$ & $\begin{array}{l}-0.112^{* * * *} \\
(-3.36)\end{array}$ \\
\hline Bubble dummy & $\begin{array}{l}33.606 * * * \\
(14.63)\end{array}$ & $\begin{array}{l}31.588 * * * \\
(12.28)\end{array}$ & $\begin{array}{l}41.660 * * * \\
(5.84)\end{array}$ & $\begin{array}{l}-0.313^{* * *} \\
(-10.49)\end{array}$ & $\begin{array}{l}-0.301 * * * \\
(-9.81)\end{array}$ & $\begin{array}{l}-0.212^{* * *} \\
(-2.71)\end{array}$ \\
\hline NASDAQ dummy & $\begin{array}{l}1.024 \\
(0.96)\end{array}$ & $\begin{array}{l}1.326 \\
(1.27)\end{array}$ & $\begin{array}{l}1.775 \\
(1.17)\end{array}$ & $\begin{array}{l}-0.090^{* * * *} \\
(-4.23)\end{array}$ & $\begin{array}{l}-0.117 * * * \\
(-5.52)\end{array}$ & $\begin{array}{l}0.037 \\
(1.30)\end{array}$ \\
\hline Observation & 5286 & 5286 & 1940 & 4150 & 4150 & 1940 \\
\hline Adjusted $\mathrm{R}^{2}$ & 0.373 & 0.387 & 0.358 & 0.171 & 0.163 & 0.053 \\
\hline
\end{tabular}




\section{Table 5. Subsample Regressions for IPO Underpricing and Shares Sold}

This table presents subsample regressions for IPO underpricing and sales, using the same models as in Table 4. Coefficients on control variables are not reported in this table. White's (1980) heteroskedasticity consistent $t$-statistic is reported in parentheses. The signs ***,**, and * represent significance levels at $1 \%, 5 \%$, and $10 \%$, respectively.

\begin{tabular}{|c|c|c|c|c|c|c|}
\hline & \multicolumn{3}{|c|}{ Dependent Variable: Initial return } & \multicolumn{3}{|c|}{ Dependent Variable: Log(Shares sold/Total shares) } \\
\hline \multicolumn{7}{|c|}{ Panel A: Subsample for 1991-1997 } \\
\hline Price range & $\begin{array}{l}0.170 * * * \\
(2.61)\end{array}$ & & & $\begin{array}{l}-0.014 \\
(-6.79)\end{array}$ & & \\
\hline | Price update | & & $\begin{array}{l}0.056^{* * * *} \\
(2.45)\end{array}$ & & & $\begin{array}{l}-0.005^{*} \\
(-3.77)\end{array}$ & \\
\hline | Residual | & & & $\begin{array}{l}15.086^{* * * *} \\
(3.66)\end{array}$ & & & $\begin{array}{l}-0.109 * * * \\
(-2.85)\end{array}$ \\
\hline Observation & 2974 & 2974 & 1395 & 2180 & 2180 & 1395 \\
\hline Adjusted $\mathrm{R}^{2}$ & 0.184 & 0.182 & 0.246 & 0.115 & 0.110 & 0.034 \\
\hline \multicolumn{7}{|c|}{ Panel B: Subsample for $1998-2004$} \\
\hline Price range & $\begin{array}{l}0.262^{*} \\
(1.75)\end{array}$ & & & $\begin{array}{l}-0.015^{\prime} \\
(-5.32)\end{array}$ & & \\
\hline | Price update | & & $\begin{array}{l}0.341^{* *} \\
(2.04)\end{array}$ & & & $\begin{array}{l}-0.004^{*} \\
(-3.95)\end{array}$ & \\
\hline | Residual | & & & $\begin{array}{l}5.707 * * * \\
(2.69)\end{array}$ & & & $\begin{array}{l}-0.042 * * \\
(-2.21)\end{array}$ \\
\hline Observation & 2312 & 2312 & 545 & 1970 & 1970 & 545 \\
\hline Adjusted $\mathrm{R}^{2}$ & 0.406 & 0.415 & 0.376 & 0.169 & 0.164 & 0.034 \\
\hline
\end{tabular}




\section{Table 6. Control for Endogeneity: Two-stage Regressions}

In Panel A, we report the first-stage regressions, in which each pre-market divergence proxy is regressed on industry excess volatility and industry average turnover ratio, controlling for year dummy variables. We downloaded 48 industry daily return series and industry classification from French's website. Each industry's excess volatility is calculated based on the industry daily return in excess of the CRSP market index return during the period of 30 trading days preceding the IPO's first trading day. Industry turnover ratio is the average turnover ratio within each industry for the 30 trading days preceding the IPO's first trading day. In Panels B and C, we report the second-stage regressions, where we use the predicted values obtained from Panel A as the proxies for the degree of pre-market opinion divergence. Panel B presents the logistic regressions for the likelihood of underpricing and Panel C presents the regressions for IPO initial return and shares sold. All control variables are included in the second-stage regressions, of which the coefficients are not reported. White's (1980) heteroskedasticity consistent $t$-statistic is reported in parentheses in Panels A and C. $p$-values are reported in parentheses in panel B. The signs ***,**, and * represent significance levels at $1 \%, 5 \%$, and $10 \%$, respectively.

Panel A: Regression of IPO Divergence Proxies on lagged market volatility and turnover ratio

\begin{tabular}{|c|c|c|c|}
\hline & Price Range & $\mid$ Price Update $\mid$ & $\mid$ Residual $\mid$ \\
\hline Intercept & $\begin{array}{l}12.904 * * * \\
(25.67)\end{array}$ & $\begin{array}{l}7.254 * * * \\
(5.49)\end{array}$ & $\begin{array}{l}0.076^{* * *} \\
(2.11)\end{array}$ \\
\hline Industry excess volatility & $\begin{array}{l}0.284^{*} \\
(1.93)\end{array}$ & $\begin{array}{l}1.558^{* *} \\
(2.36)\end{array}$ & $\begin{array}{l}0.239 * * * \\
(7.75)\end{array}$ \\
\hline Industry turnover ratio & $\begin{array}{l}0.173 * * * \\
(6.04)\end{array}$ & $\begin{array}{l}0.532 * * * \\
(7.08)\end{array}$ & $\begin{array}{l}0.025^{* * *} \\
(5.76)\end{array}$ \\
\hline Year dummies & Yes & Yes & Yes \\
\hline Observation & 5286 & 5286 & 1940 \\
\hline Adjusted $\mathrm{R}^{2}$ & 0.093 & 0.091 & 0.069 \\
\hline
\end{tabular}


Panel B: Dependent variable $=1$ if IPO return $>0$ ( 0 otherwise $)$

\begin{tabular}{ll}
\hline Predicted price range & $0.074 * * *$ \\
& $(<0.001)$
\end{tabular}

Predicted $\mid$ Price Update $\mid$ $(<0.001)$

Predicted |Residual $\mid$

$0.060 * * *$

$(<0.001)$ 


\section{Table 7. Underpriced IPOs versus Fairly Valued IPOs}

The regressions in this table make comparisons between IPOs that are, ex ante, more likely to be underpriced and those that are, ex ante, less likely to be underpriced. To do this, we first estimate the likelihood of underpricing for each IPO using the logistic models in Panel B of Table 6, and then divide the whole sample into two groups at the median likelihood. We run the regressions of IPO initial return (Panel A) and shares sold (Panel B) for each group. In order to control for potential endogeneity, we use as the independent variables the predicated values of opinion divergence obtained from Panel A of Table 6. Control variables are included in all regressions, of which the coefficients are not reported. White's (1980) heteroskedasticity consistent $t$-statistic is reported in parentheses. The signs ***,**, and * represent significance levels at $1 \%, 5 \%$, and $10 \%$, respectively. 


\begin{tabular}{|c|c|c|c|c|c|c|}
\hline & $\begin{array}{l}\text { More likely } \\
\text { underpriced }\end{array}$ & $\begin{array}{l}\text { Less likely } \\
\text { underpriced }\end{array}$ & $\begin{array}{l}\text { More likely } \\
\text { underpriced }\end{array}$ & $\begin{array}{l}\text { Less likely } \\
\text { underpriced }\end{array}$ & $\begin{array}{l}\text { More likely } \\
\text { underpriced }\end{array}$ & $\begin{array}{l}\text { Less likely } \\
\text { underpriced }\end{array}$ \\
\hline \multicolumn{7}{|c|}{ Panel A: Dependent variable = Initial return } \\
\hline Price range & $\begin{array}{l}0.832 * * * \\
(2.85)\end{array}$ & $\begin{array}{l}0.484 * * \\
(2.23)\end{array}$ & & & & \\
\hline | Price update| & & & $\begin{array}{l}0.911 * * * \\
(2.84)\end{array}$ & $\begin{array}{l}0.381 \\
(1.52)\end{array}$ & & \\
\hline | Residual | & & & & & $\begin{array}{l}19.350 * * * \\
(2.97)\end{array}$ & $\begin{array}{l}12.327 \\
(1.02)\end{array}$ \\
\hline Observation & 2645 & 2641 & 2645 & 2641 & 975 & 965 \\
\hline Adjusted $\mathrm{R}^{2}$ & 0.418 & 0.033 & 0.418 & 0.041 & 0.425 & 0.040 \\
\hline \multicolumn{7}{|c|}{ Panel B: Dependent variable $=\log ($ Shares sold $/$ Total shares $)$} \\
\hline Price range & $\begin{array}{l}-0.006 \\
(-0.69)\end{array}$ & $\begin{array}{l}-0.020 * * \\
(-2.32)\end{array}$ & & & & \\
\hline $\mid$ Price update | & & & $\begin{array}{l}0.003 \\
(0.51)\end{array}$ & $\begin{array}{l}-0.016^{* * *} \\
(-2.58)\end{array}$ & & \\
\hline | Residual | & & & & & $\begin{array}{l}-0.195 \\
(-1.25)\end{array}$ & $\begin{array}{l}-0.328 * * * \\
(-2.77)\end{array}$ \\
\hline Observation & 2077 & 2073 & 2077 & 2073 & 975 & 965 \\
\hline Adjusted $\mathrm{R}^{2}$ & 0.108 & 0.182 & 0.107 & 0.185 & 0.041 & 0.058 \\
\hline
\end{tabular}




\section{Table 8. IPO Proceeds and Pre-market Opinion Divergence}

This table presents regressions for IPO proceeds, in which the dependent variables are the nature logarithm of total amount of money raised during the IPO, including both primary and secondary amounts offered. The independent variables are the same as in the regressions for IPO initial return and shares sold reported in previous tables. Columns (1) to (3) report OLS regressions. Columns (4) to (6) report two-stage regressions in which the predicted values of opinion divergence estimated from the first-stage regressions in Table 6 are used as the independent variable. White's (1980) heteroskedasticity consistent $t$-statistic is reported in parentheses. The signs $* * *, * *$, and * represent significance levels at $1 \%, 5 \%$, and $10 \%$, respectively. 


\begin{tabular}{|c|c|c|c|c|c|c|}
\hline & \multicolumn{3}{|c|}{ OLS regressions IPO proceeds } & \multicolumn{3}{|c|}{ Two-Stage OLS regressions for IPO proceeds } \\
\hline & $(1)$ & $(2)$ & (3) & $(4)$ & $(5)$ & $(6)$ \\
\hline Intercept & $\begin{array}{l}17.857 * * * \\
(346.01)\end{array}$ & $\begin{array}{l}17.552 * * * \\
(484.45)\end{array}$ & $\begin{array}{l}17.087 * * * \\
(349.55)\end{array}$ & $\begin{array}{l}19.611 \\
(181.32)\end{array}$ & $\begin{array}{l}18.121 \\
(181.15)\end{array}$ & $\begin{array}{l}18.401 \\
(164.08)\end{array}$ \\
\hline Price range & $\begin{array}{l}-0.035 * * * \\
(-12.98)\end{array}$ & & & $\begin{array}{l}-0.169 * * * \\
(-21.29)\end{array}$ & & \\
\hline | Price update | & & $\begin{array}{l}-0.008 * * * \\
(-8.05)\end{array}$ & & & $\begin{array}{l}-0.052 * * * \\
(-6.49)\end{array}$ & \\
\hline | Residual | & & & $\begin{array}{l}-0.117 * * \\
(-2.07)\end{array}$ & & & $\begin{array}{l}-2.141^{* * *} \\
(-9.20)\end{array}$ \\
\hline Price update & $\begin{array}{l}0.007 * * * \\
(9.15)\end{array}$ & $\begin{array}{l}0.010^{* * * *} \\
(14.55)\end{array}$ & $\begin{array}{l}0.008 * * * \\
(8.16)\end{array}$ & $\begin{array}{l}0.007 * * * \\
(8.37)\end{array}$ & $\begin{array}{l}0.007 * * * \\
(8.06)\end{array}$ & $\begin{array}{l}0.007 * * * \\
(7.58)\end{array}$ \\
\hline UW rank dummy & $\begin{array}{l}0.809 * * * \\
(25.49)\end{array}$ & $\begin{array}{l}0.845^{* * *} \\
(26.89)\end{array}$ & $\begin{array}{l}0.920^{* * *} \\
(21.90)\end{array}$ & $\begin{array}{l}0.860 * * * \\
(27.87)\end{array}$ & $\begin{array}{l}0.808 * * * \\
(24.50)\end{array}$ & $\begin{array}{l}0.830 * * * \\
(23.68)\end{array}$ \\
\hline NASDAQ return & $\begin{array}{l}-0.009 * * * \\
(-3.08)\end{array}$ & $\begin{array}{l}-0.009 * * * \\
(-2.92)\end{array}$ & $\begin{array}{l}-0.001 \\
(-0.19)\end{array}$ & $\begin{array}{l}-0.003 \\
(-1.05)\end{array}$ & $\begin{array}{l}-0.004 \\
(-1.21)\end{array}$ & $\begin{array}{l}-0.003 \\
(-0.93)\end{array}$ \\
\hline VC dummy & $\begin{array}{l}-0.236 * * * \\
(-8.76)\end{array}$ & $\begin{array}{l}-0.303 * * * \\
(-11.03)\end{array}$ & $\begin{array}{l}-0.247 * * * \\
(-6.16)\end{array}$ & $\begin{array}{l}-0.332 * * * \\
(-12.50)\end{array}$ & $\begin{array}{l}-0.329 * * * \\
(-11.82)\end{array}$ & $\begin{array}{l}-0.361 * * * \\
(-12.20)\end{array}$ \\
\hline Tech dummy & $\begin{array}{l}-0.139 * * * \\
(-4.76)\end{array}$ & $\begin{array}{l}-0.190 * * * \\
(-6.45)\end{array}$ & $\begin{array}{l}-0.134 * * * \\
(-3.12)\end{array}$ & $\begin{array}{l}-0.056^{*} \\
(-1.89)\end{array}$ & $\begin{array}{l}-0.113^{* * *} \\
(-3.25)\end{array}$ & $\begin{array}{l}-0.166 * * * \\
(-5.10)\end{array}$ \\
\hline Bubble dummy & $\begin{array}{l}0.363 * * * \\
(10.47)\end{array}$ & $\begin{array}{l}0.382 * * * \\
(10.93)\end{array}$ & $\begin{array}{l}0.576^{* * * *} \\
(6.04)\end{array}$ & $\begin{array}{l}0.688 * * * \\
(18.34)\end{array}$ & $\begin{array}{l}0.984 * * * \\
(9.39)\end{array}$ & $\begin{array}{l}2.116^{* * *} \\
(10.97)\end{array}$ \\
\hline NASDAQ dummy & $\begin{array}{l}-0.315^{* * * *} \\
(-11.30)\end{array}$ & $\begin{array}{l}-0.397 * * * \\
(-14.30)\end{array}$ & $\begin{array}{l}-0.252 * * * \\
(-6.22)\end{array}$ & $\begin{array}{l}-0.324 * * * \\
(-11.91)\end{array}$ & $\begin{array}{l}-0.386^{* * * *} \\
(-13.35)\end{array}$ & $\begin{array}{l}-0.377 * * * \\
(-12.28)\end{array}$ \\
\hline Observation & 5286 & 5286 & 1940 & 5286 & 5286 & 1940 \\
\hline Adjusted $\mathrm{R}^{2}$ & 0.280 & 0.248 & 0.305 & 0.321 & 0.248 & 0.263 \\
\hline
\end{tabular}




\section{Table 9. Aftermarket Opinion Divergence and IPO Underpricing and Sales}

In Panel A we report the first-stage regressions, which are the regressions of two aftermarket opinion divergence variables on each pre-market opinion divergence variable. The aftermarket divergence variables are analyst dispersion in long-term growth forecast (ADIGF) and the 60 trading-day market-adjusted daily return volatility (TDDRV). In Panels B and C, we report the second-stage regressions, in which IPO initial return and shares sold are regressed on the fitted and residual components of each aftermarket divergence variable that are obtained from the first-stage regression. All control variables are included in the regressions in Panels B and C, of which the coefficients are not reported White's (1980) heteroskedasticity consistent $t$-statistic is reported in parentheses. The signs ***, **, and $*$ represent significance levels at $1 \%, 5 \%$, and $10 \%$, respectively.

Panel A: Regressions of aftermarket opinion divergence measures on pre-market opinion divergence measures

\begin{tabular}{|c|c|c|c|c|c|c|}
\hline \multirow{2}{*}{$\begin{array}{l}\text { Independent variables } \\
\text { Intercept }\end{array}$} & \multicolumn{3}{|c|}{ Dependent variable: ADIGF } & \multicolumn{3}{|c|}{ Dependent variable: TDDRV } \\
\hline & $\begin{array}{l}4.848^{* * *} \\
(11.34)\end{array}$ & $\begin{array}{l}4.930 * * * \\
(21.05)\end{array}$ & $\begin{array}{l}4.822^{* * * *} \\
(16.20)\end{array}$ & $\begin{array}{l}2.666^{* * *} \\
(31.93)\end{array}$ & $\begin{array}{l}3.475^{* * * *} \\
(46.88)\end{array}$ & $\begin{array}{l}3.476^{* * * *} \\
(30.97)\end{array}$ \\
\hline Price range & $\begin{array}{l}0.098^{* * * *} \\
(3.30)\end{array}$ & & & $\begin{array}{l}0.094 * * * \\
(15.72)\end{array}$ & & \\
\hline | Price update | & & $\begin{array}{l}0.082 * * * \\
(6.54)\end{array}$ & & & $\begin{array}{l}0.032 * * * \\
(6.54)\end{array}$ & \\
\hline | Residual | & & & $\begin{array}{l}1.399 * * * \\
(3.34)\end{array}$ & & & $\begin{array}{l}0.716^{* * * *} \\
(2.70)\end{array}$ \\
\hline Observation & 1966 & 1966 & 832 & 3860 & 3860 & 1421 \\
\hline Adjusted $\mathrm{R}^{2}$ & 0.040 & 0.037 & 0.020 & 0.089 & 0.070 & 0.069 \\
\hline
\end{tabular}


Panel B: ADIGF as the measure of aftermarket divergence

\begin{tabular}{|c|c|c|c|c|c|c|}
\hline \multirow[b]{2}{*}{ Independent variable } & \multicolumn{3}{|c|}{ Regressions of IPO initial return } & \multicolumn{3}{|c|}{ Regressions of shares sold } \\
\hline & Price range & | Price update | & | Residual | & Prince range & | Price update | & | Residual | \\
\hline Predicted ADIGF & $\begin{array}{l}2.105 * * * \\
(3.79)\end{array}$ & $\begin{array}{l}8.274 * * * \\
(7.88)\end{array}$ & $\begin{array}{l}5.934 * * * \\
(3.40)\end{array}$ & $\begin{array}{l}-0.019 * * \\
(-2.49)\end{array}$ & $\begin{array}{l}-0.063 * * * \\
(-4.61)\end{array}$ & $\begin{array}{l}-0.060 * * * \\
(-3.62)\end{array}$ \\
\hline Residual ADIGF & $\begin{array}{l}0.556 \\
(1.38)\end{array}$ & $\begin{array}{l}0.464 * * * \\
(3.25)\end{array}$ & $\begin{array}{l}0.436^{*} \\
(1.65)\end{array}$ & $\begin{array}{l}-0.006 \\
(-0.47)\end{array}$ & $\begin{array}{l}-0.005^{* *} \\
(-2.25)\end{array}$ & $\begin{array}{l}-0.004 \\
(-1.28)\end{array}$ \\
\hline Observation & 1966 & 1966 & 832 & 1557 & 1557 & 832 \\
\hline Adjusted $\mathrm{R}^{2}$ & 0.509 & 0.548 & 0.449 & 0.129 & 0.138 & 0.081 \\
\hline
\end{tabular}

Panel C: TDDRV as the measure of aftermarket divergence

\begin{tabular}{|c|c|c|c|c|c|c|}
\hline \multirow[b]{2}{*}{ Independent variable } & \multicolumn{3}{|c|}{ Regressions of IPO initial return } & \multicolumn{3}{|c|}{ Regressions of shares sold } \\
\hline & Price range & | Price update $\mid$ & | Residual | & Prince range & | Price update | & | Residual | \\
\hline Predicted TDDRV & $\begin{array}{l}4.013 * * * \\
(4.54)\end{array}$ & $\begin{array}{l}10.028^{* * *} \\
(4.15)\end{array}$ & $\begin{array}{l}9.439^{*} \\
(1.83)\end{array}$ & $\begin{array}{l}-0.278 * * * \\
(-9.22)\end{array}$ & $\begin{array}{l}-0.196 * * * \\
(-5.95)\end{array}$ & $\begin{array}{l}-0.111 * * * \\
(-4.15)\end{array}$ \\
\hline Residual TDDRV & $\begin{array}{l}2.111 * * * \\
(3.32)\end{array}$ & $\begin{array}{l}1.933 * * * \\
(2.55)\end{array}$ & $\begin{array}{l}0.801 \\
(1.03)\end{array}$ & $\begin{array}{l}-0.028 * * * \\
(-3.86)\end{array}$ & $\begin{array}{l}-0.027 * * * \\
(-4.01)\end{array}$ & $\begin{array}{l}-0.025^{* *} \\
(-2.20)\end{array}$ \\
\hline Observation & 3860 & 3860 & 1421 & 3061 & 3061 & 1421 \\
\hline Adjusted $\mathrm{R}^{2}$ & 0.377 & 0.386 & 0.406 & 0.188 & 0.177 & 0.068 \\
\hline
\end{tabular}

